\title{
Insecticidal activity of volcanic ash against Sitophilus oryzae L. (Coleoptera: Curculionidae) under laboratory conditions
}

\author{
Micaela Buteler ${ }^{1}$; Guillermo P. López García ${ }^{2, \otimes ;}$; Arístides A. Pochettino²; Natalia \\ Stefanazzi ${ }^{3}$; Adriana A. Ferrero ${ }^{3} \&$ Teodoro Stadler ${ }^{2}$ \\ 1. Laboratorio Ecotono, INIBIOMA, CONICET, Río Negro, Argentina. 2. Laboratorio de Toxicología Ambiental, IMBECU \\ CONICET, Mendoza, Argentina. 3. Laboratorio de Zoología de Invertebrados II, Dpto. de Biología, Bioquímica y Farmacia, \\ Universidad Nacional del Sur, Bahía Blanca, Argentina
}

\begin{abstract}
Aвstract. This study assessed the acute toxicity and repellence as well as feeding deterrence effect of volcanic ash (VA) on Sitophilus oryzae adults under laboratory conditions. VA resulted in significant adult mortality of S. oryzae. Acute toxicity of the VA was similar to that of commercially available diatomaceous earth DiatomiD ${ }^{\circledR}$ demonstrating its insecticidal potential. Median lethal concentration values $\left(\mathrm{LC}_{50}\right)$ obtained were 1610 [1449, $1778] \mathrm{mg} / \mathrm{kg}$ for VA and $1046[916,1168] \mathrm{mg} / \mathrm{kg}$ for DiatomiD ${ }^{\circledR}$.Similarly to other inert dusts, VA particle size shows a bi-modal distribution and porosity which increases its surface area. Among the smallest particles, the highest volumetric loading was close to $5 \mu \mathrm{m}$ with a distribution of smaller particles peaking at $0.5 \mu \mathrm{m}$. Results indicate that VA is not repellent to S. oryzae. An "engagement" response or increased interaction of the insects with the VA treated surface was observed. However, feeding deterrence indices showed that both VA and diatomaceous earth had strong feeding deterrent action. Contact of insects with VA may lead to mortality by adherence of the VA particles to the insect cuticle. However, insects prefer feeding on sites without VA covered substrates and this could have a positive impact on its use for pest management.
\end{abstract}

[Keywords: repellence, feeding deterrence, acute toxicity, Coleoptera]

\begin{abstract}
Resumen: Actividad insecticida de la ceniza volcánica en un insecto plaga, Sitophilus oryzae L. (Coleoptera: Curculionidae) bajo condiciones de laboratorio: En este estudio se evaluó la toxicidad aguda, repelencia y fagodisuación alimenticia de las cenizas volcánicas (VA) en adultos de Sitophilus oryzae y en condiciones de laboratorio. VA causó mortalidad significativa de S. oryzae. Su toxicidad aguda fue similar a la de la tierra de diatomeas comercial DiatomiD ${ }^{\circledR}$ demostrando su potencial como producto insecticida. Los valores de concentración letal media $\left(\mathrm{CL}_{50}\right)$ obtenidos fueron de $1610[1449,1778] \mathrm{mg} / \mathrm{kg}$ para VA y $1046[916,1168] \mathrm{mg} / \mathrm{kg}$ para DiatomiD ${ }^{\circledR}$. De manera similar a otros polvos inertes, la distribución del tamaño de partícula de VA es bi-modal con una porosidad que aumenta su área de superficie. Entre las partículas más pequeñas, la más alta carga volumétrica estaba cerca de $5 \mu \mathrm{m}$ con una distribución de partículas más pequeñas alcanzando un máximo de $0,5 \mu \mathrm{m}$. Los resultados indican que la VA no es repelente para S. oryzae. De hecho, se observó una respuesta de "acoplamiento" o aumento de la interacción de los insectos con la superficie tratada con VA. Sin embargo, los índices de fagodisuasión alimenticia mostraron que tanto la tierra de diatomeas como la VA tuvieron una fuerte acción disuasiva de la alimentación. Los resultados sugieren que los insectos se pondrán en contacto con el polvo de una superficie tratada con VA dado que no hay repelencia, conduciendo a la mortalidad de los mismos por la adhesión de las partículas de VA a la cutícula. Sin embargo, los insectos prefieren alimentarse en sitios sin VA y esto podría tener un impacto positivo en su uso para el manejo de insectos.
\end{abstract}

[Palabras clave: repelencia, fagodisuación alimenticia, toxicidad aguda, Coleoptera]

\section{INTRODUCTION}

Inorganic dusts have been historically used for pest control, and since the 1920s sold for the protection of stored grains given their efficacy and low toxicity for non target organisms and the environment (Ebeling 1971; Golob 1997; Subramanyam \& Roesli 2000). One of the most commonly used insecticidal inert powder is diatomaceous earth (DE), which is obtained from geological deposits of fossilized microscopic algae whose composition

Editora asociada: Adriana Ruggiero

lpe@lab.cricyt.edu.ar is largely silicon dioxide $\left(\mathrm{SiO}_{2}\right)$ (Ebeling 1971; Golob 1997). Furthermore, the newly discovered nanoinsecticide (NSA) based on nanostructured alumina $\left(\mathrm{Al}_{2} \mathrm{O}_{3}\right)$ (Stadler et al. 2010, 2011), represents a new type of particulate material with a similar mode of action to that of insecticide inert powders.

Another type of inert dust results from volcanic eruptions, which are among the main natural producers of ultrafine particles (Ammann et al. 1990) and volcanic ash has insecticidal effects (Edwards \& Schwartz

Recibido: 5 de julio de 2013; Fin de arbitraje: 10 de septiembre; Última versión: 15 de octubre; Aceptado: 26 de noviembre. 
1981; Marske et al. 2007; Buteler et al. 2011). It is likely that the toxicity of volcanic ash from the Puyehue Cordon Caulle eruption is similar to that of DE and NSA, based on the presence of fine and ultrafine particles and due to the preponderance of glass shards $\left(\mathrm{SiO}_{2}\right)$ and aluminum $\left(\mathrm{Al}_{2} \mathrm{O}_{3}\right)$ (Bermudez \& Delpino 2011; Mogni et al. 2011).

DE and inert dusts in general, are thought to kill insects by removing cuticular waxes which leads to desiccation (Subramanyam \& Roesli 2000). The biological activity of the inert powders increases as particle size decreases, as a result of the direct correlation between the surface / volume ratio per unit weight and the surface energy of the particle (Paull \& Lyons 2008). It is thought that particles in the micrometer scale are responsible for the sorption of waxes from the insect epicuticle and the larger particles, which could act as abrasive, may add only a small proportion of the insecticidal effect (Mewis \& Ulrichs 1999).

So far, only a few controlled studies have been published on the impact of VA from the Puyehue-Caulle Range eruption. Buteler et al. (2011) and Fernández-Arhex et al. (2013) demonstrated the toxicity of volcanic ash from Puyehue-Caulle Range on two coleopteran species of the families Silvanidae and Tenebrionidae, and on one Acriidid locusts species, respectively. Moreover, the research on sub-lethal effects of volcanic ash and inert dusts on insects in general is very limited. Repellence of wheat treated with diatomaceous earth has been reported in only a few cases (White et al. 1966; Rigaux et al. 2001).

Therefore, the purpose of this study was to examine and better understand the acute toxicity and the sub-lethal effects of repellence and feeding deterrence of the volcanic ash from Puyehue-Caulle Range on a chewing insect and stored grain pest Sitophilus oryzae L. (Coleoptera: Curculionidae) under controlled conditions. We also conducted a particle size analysis of VA given the known correlation between particle size of inert dusts and their toxicity.

\section{Materials And Methods}

\section{Volcanic ash}

Volcanic ash was collected in Collon Cura $\left(40^{\circ}\right.$ $\left.02^{\prime} 24^{\prime \prime} \mathrm{S}, 70^{\circ} 14^{\prime} 26^{\prime \prime} \mathrm{W}\right)$, Neuquen, Argentina, during the first days of the eruption (15/06/11). Three random samples were collected from ash deposited on the ground and placed in plastic bags. The samples were combined for the analysis. The particle size distribution of the volcanic ash was analysed with a dynamic light scattering system (Malvern Instrument Zetasizer Nano ZS). Samples were ultrasonicated for $5 \mathrm{~min}$ in water at $20 \%$ power (Branson $20 \mathrm{kHz} 200$ watt Sonifier) utilizing an ammonium polymethacrylate dispersant (Darvan C-N, RT Vanderbilt). This procedure is conducted to disperse the particles in the water to take a more accurate measurement. Slightly turbid solutions at approximately $1 \mathrm{wt} \%$ solids were characterized in disposable polystyrene cuvettes to eliminate cross contamination between samples.

Commercial diatomaceous earth DiatomiD ${ }^{\circledR}$ was used as positive control (Active Ingredient: 100\% Diatomaceous earth, raw mineral; Density: 0.54 $\left.\mathrm{g} / \mathrm{cm}^{3} ; \mathrm{pH} 9.4\right)$.

\section{Tested insects}

The insects tested were adults of S. oryzae, the rice weevil. Insects were reared at the Laboratory of Environmental Toxicology IMBECU CONICET CCT-Mendoza on wheat kernels and had no history of exposure to insecticides. Insects were kept in a growth chamber at $27^{\circ} \pm 1^{\circ} \mathrm{C}$ and $70 \% \pm 5 \% \mathrm{RH}$, and continuous darkness. The desired $\mathrm{RH}$ was maintained by using a saturated solution of sodium chloride in water (Winston \& Bates 1960). Bioassays were conducted under the same conditions.

\section{Contact toxicity bioassay}

A contact toxicity bioassay was conducted to determine the toxicity of the VA and that of a known insecticide, DiatomiD ${ }^{\circledR}(\mathrm{DE})$. The VA and DE were mixed separately with clean dry wheat kernels with a moisture content of $14 \%$. Wheat used for the experiments was NIDERA var. Baguette 501.

Different amounts of the dusts were mixed with the wheat and shaken for $1 \mathrm{~min}$ to obtain an even distribution on the seed surface. Treatments consisted of four different concentrations of VA and four concentrations of DE in $20 \mathrm{~g}$ of wheat kernels $(4500,3500,2500$ and $1500 \mathrm{mg} / \mathrm{kg})$ in a Petri dish. Untreated wheat kernels were used as control. Ten unsexed adults of S. oryzae 1-42 days old were placed in each Petri dish.

The experimental design was totally randomized with 10 replicates. The experiments were carried out in a dark growth chamber at $27^{\circ} \pm 1^{\circ} \mathrm{C}$ and $70 \pm 5 \%$ RH. For all treatments, the mortality was assessed six days after continuous exposure.

Mortality data were analyzed using the Mixed Procedure (PROC MIXED) of the Statistical Analysis System (SAS 2001) with mortality as the response variable and concentration, treatment, and their interaction as main effects. Petri dish replicates were included as a random factor. Control mortality was corrected using Abbott's (1925) formula. 
LSMEANS comparisons were conducted with the Tukey option in SAS.

The $\mathrm{LC}_{50}$ and $\mathrm{LC}_{95}$ values $(\mathrm{mg} / \mathrm{kg})$ and $95 \%$ confidence limits (95\% CLs) were calculated by Probit analysis (SAS 2001) at 6 days after continuous exposure to the treated substrate. The chi squared value was used to measure the goodness of fit of the Probit regression line.

\section{Repellence activity bioassay}

Repellence of VA on S. oryzae was assessed by using a modification of the area preference test (Mc Donald et al. 1970) to account for the use of a solid non-sublimable product instead of a volatile liquid. This variant of the method doesn't include food given that it can have a confounding effect. Also, ash particles where glued to the bottom of the test cage to limit adherence of the particles to the insect cuticle that would lead to contact toxicity. The aim was to provide data on repellence only, excluding contact toxicity and deterrence phenomena.

Bioassays were carried out in a cylindrical arena consisting of a $9.5 \mathrm{~cm}$ diameter Petri dish, divided in two equal sections with a septum. A thin layer of a water suspension of glue (polyvinyl acetate, CAS $n^{\circ}$ 9003-20-7) was applied on the whole surface of the Petri dish (bottom and lids) and volcanic ash was spread in excess over half of the sticky surface. The other half of the Petri dish remained free of VA particles. Treated Petri dishes were placed in a desiccation oven during 24 hours at $50^{\circ} \mathrm{C}$. Further, the excess of ash was removed to keep only the glued ash particles on the dish surface. Excess particles would cause lethal or sub-lethal undesired effects during the repellence test. Even though there were slight variations in the amount of VA on the treated surface, it was completely covered with dust in all cases so we consider the bioassay design appropriate to test repellence.

Ten adult beetles were released in the middle of each Petri dish. The dishes were placed in the growth chamber and the number of insects on each half of the arena was recorded 12 hours later. Five replicates of the trial were performed.

Data were analyzed using the following formula for repellence percentage (RP) according to Talukder \& House (1993): RP $=2$ x (C-50).

\section{Feeding deterrence bioassay}

A two-choice feeding deterrence test was conducted in $9.5 \mathrm{~cm}$ diameter Petri dishes. Treatments consisted of $1500 \mathrm{mg} / \mathrm{kg}$ of VA or DE in $4 \mathrm{~g}$ of wheat substrate. The dusts were mixed with clean dry wheat kernels and shaken for 1 min to obtain an even distribution of the particles on the seed surface. The arena in the Petri dishes was divided in two sections by a septum. One section contained $4 \mathrm{~g}$ of treated wheat grain and the opposite side contained $4 \mathrm{~g}$ of untreated grain.

Ten adult beetles were released in each Petri dish. The Petri dishes were placed in the growth chamber. The number of insects on each section of the arena was recorded 30 hours after the start of the test. Five replicates were performed for each treatment (VA and DE). Data were analyzed using the distribution coefficient (DC) (Stefanazzi et al. 2011), which is the quotient between the difference of individuals in the control arena and treated arena and their sum (indicated as percentage). Therefore, positive values express repellence and negative values expressed attractiveness.

\section{Results}

\section{Particle size and morphology}

Volcanic ash was composed of a majority of particles approximately $50-100 \mu \mathrm{m}$ in diameter (Figure 1). The analysis indicates a bi-modal distribution of particle size as well as porosity in the larger particles, which serves to increase its overall surface area. Among the smallest particles, the highest volumetric loading was

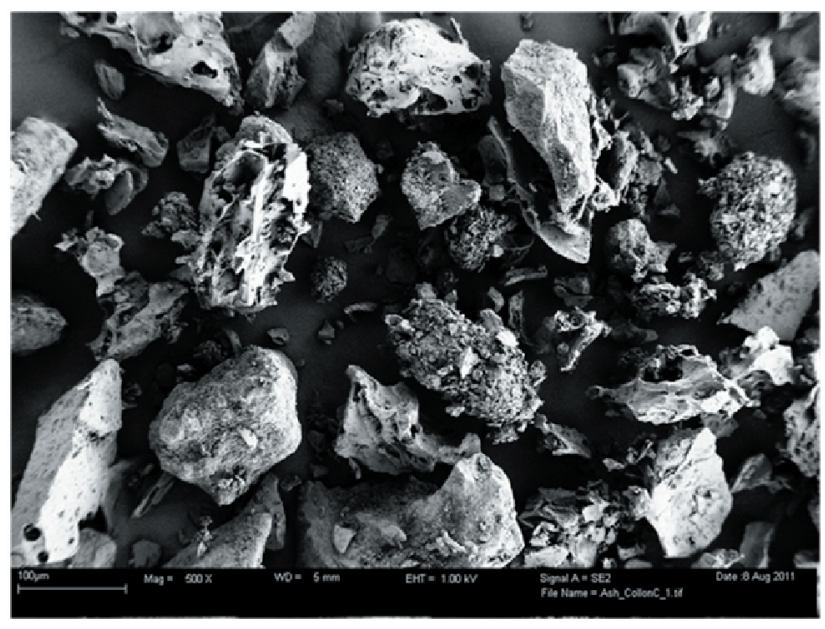

Figure 1. Scanning Electron Microscope Picture of volcanic ash. EHT: $1 \mathrm{kV}$, WD: $5 \mathrm{~mm}$. Magnification: $500 \mathrm{x}$.

Figura 1. Imagen de Microscopio Electrónico de Barrido de las cenizas volcánicas. EHT: $1 \mathrm{kV}, \mathrm{WD}$ : $5 \mathrm{~mm}$. Ampliación: 500 x. 


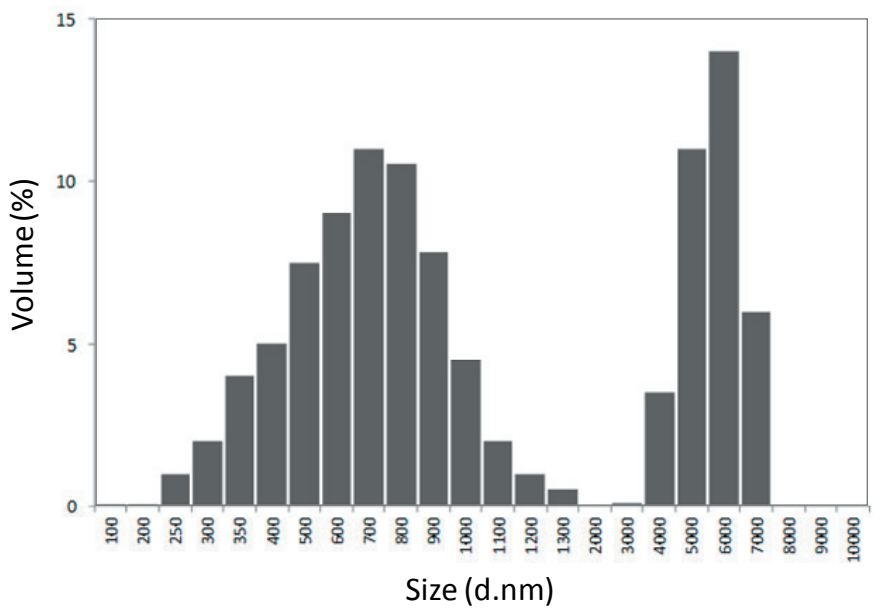

Figure 2. Laser scattering particle size distributions of volcanic ash, in water with ammonium polymethacrylate dispersant. d.nm=particle diameter in nanometers.

Figura 2. Distribuciones de tamaño de partícula de ceniza volcánica, obtenido mediante dispersión en laser; se utilizo agua y polimetacrilato de amonio como dispersante. d.nm = diámetro de partícula en nanómetros. close to $5 \mu \mathrm{m}$ with a distribution of smaller particles peaking at $0.5 \mu \mathrm{m}$ (Figure 2 ).

\section{Adult mortality, repellence and feeding deterrence}

Both types of dust tested resulted in significant adult mortality of $S$. oryzae although DE was more toxic than VA at the lower doses $(\mathrm{F}=143$, d.f. $=1,99, \mathrm{P}<0.0001)$ (Table 1). As expected, toxicity increased with concentration of the dust $(\mathrm{F}=828$, d.f. $=5,99$, $\mathrm{P}<0.0001)$. At the higher concentration both dusts caused similar mortality, around 100\% and $97 \%$ mortality respectively. Probit analysis also showed that the $\mathrm{LC}_{50}$ (6days) was lower for DE than for the VA but the slopes were similar which explains why at higher doses there was no difference in the toxicity between the two dusts (Table 2).

As shown on Table 3, based on the DC values obtained volcanic ash is not repellent to $S$. oryzae. The bioassay results were assessed by

Table 1. Percentage of mortality of adult S. oryzae from acute toxicity bioassays - dry dust application of Volcanic Ash (VA) and Diatomaceous earth (DE). Bioassay endpoint $=6$ days; $n=10$; substrate $=$ treated wheat kernels.

Tabla 1. Porcentaje de mortalidad de adultos de S. oryzae en bioensayos de toxicidad aguda mediante la aplicación en seco de cenizas volcánicas (VA) y tierra de diatomeas (DE). Punto final del bioensayo $=6$ días, $\mathrm{n}=10$; sustrato = granos de trigo tratados.

\begin{tabular}{lcc}
\hline Concentration & \multicolumn{2}{c}{ Mortality \% at day 6 (Mean \pm SE) } \\
\cline { 2 - 3 } $\mathrm{mg} / \mathrm{kg}$ & $\mathrm{DE}$ & $\mathrm{VA}$ \\
\hline 4500 & $100 \pm 0$ & $97 \pm 1.5$ \\
3500 & $97 \pm 1.5$ & $84 \pm 2.2$ \\
2500 & $85 \pm 1.6$ & $68 \pm 2.0$ \\
1500 & $70 \pm 2.1$ & $38 \pm 2.9$ \\
750 & $33 \pm 2.6$ & $21 \pm 2.3$ \\
0 & $0 \pm 0$ & $0 \pm 0$ \\
\hline
\end{tabular}

Table 2. Probit analysis of mortality data on Sitophilus oryzae exposed to volcanic ash (VA) and DiatomiD ${ }^{\circledR}(\mathrm{DE})$; endpoint $=6$ days; $\mathrm{n}=10$; substrate $=$ treated wheat kernels.

Tabla 2. Análisis Probit de los datos de mortalidad de Sitophilus oryzae expuesto a cenizas volcánicas (VA) y DiatomiD ${ }^{\circledR}(\mathrm{DE})$; punto final $=6$ días, $\mathrm{n}=$ 10; sustrato $=$ granos de trigo tratados.

\begin{tabular}{lccc}
\hline Treatment & $\mathrm{LC}_{50}(\mathrm{CI})(\mathrm{ppm})$ & Slope & $\begin{array}{c}\text { Goodness of fit } \\
\text { Chi square } / \mathrm{P} \\
\text { value }\end{array}$ \\
\hline $\mathrm{DE}$ & $1046(916,1168)$ & $3.35 \pm 0.29$ & $0.42 / 0.99$ \\
VA & $1610(1449,1778)$ & $3.07 \pm 0.25$ & $0.61 / 0.98$ \\
\hline
\end{tabular}

using the Miller et al (2009) criteria, adopting the term "engagement" when an increased interaction of the insect with the stimulus was observed. According to these authors, the values of $D C \geq-60$ observed would indicate a "sustained interaction of a responder with the stimulus source". Therefore, VA is a

Table 3. Results from the repellence activity bioassay on volcanic ash (VA). Ten insects were placed in each arena and 12 hours afterwards, the distribution of insects in the arena was recorded; $\mathrm{n}=10 ; \mathrm{DC}=$ distribution coefficient.

Table 3. Resultados de repelencia en bioensayo con cenizas volcánicas (VA). Diez insectos se colocaron en cada arena y 12 horas después, se registró la distribución de los insectos en la arena, $\mathrm{n}=10 ; \mathrm{DC}=$ coeficiente de distribución.

\begin{tabular}{lccc}
\hline Run & Area of the Arena & $\mathrm{N}^{\circ}$ insects per area & DC (15hs) \\
\hline 1 & Treated & 10 & -100 \\
& Control & 0 & \\
2 & Treated & 8 & -60 \\
& Control & 2 & \\
3 & Treated & 6 & -20 \\
& Control & 4 & \\
4 & Treated & 8 & -60 \\
& Control & 2 & \\
5 & Treated VA & 7 & -40 \\
& Untreated & 3 & \\
\hline
\end{tabular}


"tactic attractant (contact stimulus)" that causes an "engagement" response (Miller et al. 2009) of $S$. oryzae to a VA treated surface. Feeding deterrence indices showed that both VA and DE had strong feeding deterrent action (Table 4).

Table 4. Distribution of insects in the different zones of the arena in the feeding deterrence test on volcanic ash and diatomaceous earth (positive control). Insects in each arena were recorded after 30 hours. $\mathrm{DC}=$ distribution coefficient.

Tabla 4. Distribución de los insectos en las diferentes zonas de la arena en la prueba de la disuasión alimenticia con cenizas volcánicas y tierra de diatomeas (control positivo). Se registró el número de insectos en cada zona después de 30 horas. DC = coeficiente de distribución.

\begin{tabular}{|c|c|c|c|c|c|}
\hline Run & $\begin{array}{l}\text { Arena } \\
\text { zones }\end{array}$ & $\begin{array}{l}\mathrm{N}^{\circ} \text { insects } \\
\text { feeding } \\
\text { on kernels } \\
\text { treated with } \\
\text { Volcanic ash }\end{array}$ & $\begin{array}{c}\mathrm{DC} \\
(30 \mathrm{~h})\end{array}$ & $\begin{array}{c}\mathrm{N}^{\circ} \text { insects } \\
\text { feeding } \\
\text { on kernels } \\
\text { treated with } \\
\text { Diatomaceous } \\
\text { earth }\end{array}$ & $\begin{array}{c}\text { DC } \\
(30 \mathrm{~h})\end{array}$ \\
\hline \multirow[t]{2}{*}{1} & $\mathrm{~T}^{\#}$ wheat & 1 & 80 & 3 & 40 \\
\hline & $\mathrm{U}^{\$}$ wheat & 9 & & 7 & \\
\hline \multirow[t]{2}{*}{2} & $\mathrm{~T}$ wheat & 3 & 40 & 1 & 80 \\
\hline & U wheat & 7 & & 9 & \\
\hline \multirow[t]{2}{*}{3} & T wheat & 2 & 60 & 3 & 40 \\
\hline & U wheat & 8 & & 7 & \\
\hline \multirow[t]{2}{*}{4} & T wheat & 2 & 60 & 0 & 100 \\
\hline & U wheat & 8 & & 10 & \\
\hline \multirow[t]{2}{*}{5} & T wheat & 1 & 80 & 3 & 40 \\
\hline & U wheat & 9 & & 7 & \\
\hline
\end{tabular}

\# T= Treated; $\$ \mathrm{U}=$ Untreated

\section{DISCUSSION}

In this study, VA was found to be highly effective in inducing mortality of adult $S$. oryzae. VA $\left(\mathrm{LC}_{50}=1610[1449,1778] \mathrm{mg} /\right.$ $\mathrm{kg}$ ) had similar lethal dose values as DE $\left(\mathrm{LC}_{50}=1046[916,1168] \mathrm{mg} / \mathrm{kg}\right)$ when tested under the same conditions. Similar toxicity data were previously reported by Buteler et al. (2011) on Oryzaephilus surinamensis L. and Tribolium castaneum (Herbst) using VA from the same eruption. These results clearly reflect the overall toxicity potential of VA given that its toxicity is similar to that of a commercial product.

Inert powders generally do not exert their toxic action through biochemical mechanisms as organic pesticides do, but through physical phenomena such as abrasion, cuticular hydrocarbon adsorption and desiccation (Subramanyam \& Roesli 2000). Particle size is a key feature of inert dusts that correlates with insect toxicity and the smaller the particle size, greater the toxicity (Chiu 1939a, b). Recommended particle size distribution for commercial DE ranges from 1 to 50 microns (Subramanyam \& Roesli 2000). The volcanic ash studied shows a bimodal particle size distribution with particles in the micrometer scale. It is likely that these smaller particles are the ones responsible for its toxicity. Thus, we think the toxicity of VA could be further enhanced by separating or extracting the smaller particles contained in the ash. Further research is necessary to develop a methodology to do that.

In the framework of the repellence phenomena of inert dust to insects described by different authors (White et al. 1966; Quarles 1992; Rigaux et al. 2001) our experiments were carried out to determine whether there was any evidence for avoidance of VA deposits by the insects when given a choice between treated and untreated surfaces. The test method used excluded food in order to prevent any kind of interference, and therefore, the test result provides information exclusively on repellence. Nevertheless, the results of the repellence activity test show at prima facie a strong attractant effect or rather indicate that VA causes "engagement" of the insects with the dust according to Miller et al. (2009). The fact that more insects were found in the VA treated area of the arena could be related to the fact that VA offers a rough or textured surface where it could be easier to walk on, compared with the smooth control section of the arena.

The absence of insect repellence to VA is not surprising given that VA main components are inorganic, non-reactive, non-volatile and insoluble, in other words, inert compounds. On the other hand, the results of the feeding deterrence bioassays show that VA is a strong deterrent. S. oryzae displayed a marked behavioral response avoiding feeding on wheat kernels treated with VA. This deterrent effect is undoubtedly not linked to repellence, but could prove useful in a pest management scenario e.g. by decreasing the feeding damage in treated grain.

VA could have an impact on herbivorous chewing insects by either physically restricting the feeding activities or causing wear on their mandibles when feeding on treated hosts. Moreover, the effect of VA on insect feeding can lead to sub-lethal consequences. For example, mechanical constraints can act in a complex way on insect feeding organs as well as on feeding time, such that delayed access to nutrients alter the ratio of assimilated 
nutrients, thereby constraining growth and development (Raupp 1985; Clissold et al. 2006). Therefore, it is likely that not only will VA cause mortality of individuals but will also impact insect growth and reproduction of exposed insects.

These results suggest that VA has potential as a stored grain protectant given its toxicity and feeding deterrence. Application rates would be similar as other commercially available inert dusts. Insects in VA covered substrates will not be repelled by the VA and thus will pick up the dust which may lead to contact mortality. Moreover, insects will prefer feeding on substrates without VA, which could protect treated grain from feeding damage of those insects that survive.

Acknowledgements. This study was funded by CONICET PIP N¹1220100100360.

\section{REFERENCES}

Аввотт, WS. 1925. A method of computing the effectiveness of an insecticide. J. Econ. Entomol., 18:265-267.

Ammann, M; H Burtscher \& HC Siegmann. 1990. Monitoring volcanic activity by characterization of ultrafine aerosol emissions. J. Aerosol Sci., 21:275-278.

Bermudez, A \& D Delpino. 2011. La actividad el volcán Puyehue y su impacto sobre el territorio de la República Argentina. Primer Informe, Neuquén, 14 de Junio de 2011 [Available at: http://medicina.uncoma.edu.ar/ download/academica/impacto_de_la_actividad_del_ volcan_puyehue.pdf (downloaded on 19/11/13)].

Buteler, M; T Stadler; GP López García; MS Lass \& D Trombotto-Liaudat. 2011. Propiedades insecticidas de la ceniza del complejo volcánico Puyehue-Cordón Caulle y su posible impacto ambiental. Rev. Soc. Entomol. Argent., 70:149-156.

Clissold, F; GD Sanson \& J Read. 2006. The paradoxical effects of nutrient ratios and supply rates on an out breaking insect herbivore, the Australian plague locust. J. Anim. Ecol., 75:1000-1013.

Ebeling, E. 1971. Sorptive dusts for pest control. Annu. Rev. Entomol., 16:23-158.

EDWARDS, JS \& LM SCHWARTz. 1981. Mount St. Helens ash: a natural insecticide. Can. J. Zool., 59:714-715.

FERnÁndeZ-ArHex, V; M Buteler; ME AMAdio; A EnRIQUEZ; AL Pietrantuono et AL. 2013. The effects of volcanic ash from Puyehue-Caulle Range eruption on the survival of Dichroplus vittigerum (Orthoptera: Acrididae). Fl. Ent., 96:286-288.

Mc Donald, L; RH GuY \& RD SpeIRs. 1970. Preliminary evaluation of new candidate materials as toxicants, repellents and attractants against stored product insects
- I. Marketing Research Report No.882. Agricultural Research Service, U.S. Department of Agriculture, Washington DC: 8pp.

MARsKe, KA; MA Ivie \& GM Hilton. 2007. Effects of volcanic ash on the forest canopy insects of Montserrat, West Indies. Environ Entomol., 6:817-25.

MeWIS, I \& C UlRICHS. 1999. Mode of action of amorphous diatomaceous earths on stored product insects - Studies on the abrasive and sorptive effects. J. Pest Sci., 72: 113-121.

Miller, JR; PY Siegert; FA Amimo \& ED Walker. 2009. Designation of Chemicals in Terms of the Locomotor Responses They Elicit From Insects: An Update of Dethier et al. (1960). J. Econ Ent, 102:2056-2060.

Mogni, L; C Cotaro \& R Daga. 2011. Análisis preliminar cenizas volcánicas sistema Puyehue-Cordón Caulle - 04-06-11 [Available at : http:/ /www.cnea.gov.ar/ pdfs/noticias/2011/InformePreliminarCenizasPuyeh ueCAB.pdf (downloaded on 19/11/13].

Paull, J \& K Lyons. 2008. Nanotechnology: the next challenge for organics. J. Org. Syst., 3: 3-22.

QuARLES, W. 1992. Diatomaceous earth for pest control. The IPM Practitioner. Volume XIV, Number 5-6: 16pp.

RAuPP, MJ. 1985. Effects of leaf toughness on mandibular wear of the leaf beetle, Plagiodera versicolor. Ecol. Ent., 10:73-79.

Rigaux, M; E Haubruge \& PG Fields. 2001. Mechanisms for tolerance to diatomaceous earth between strains of Tribolium castaneum. Entomol. Exp. Appl., 101:33-39.

SAS. 2001. User's Guide. SAS Institute, Cary, NC.

Stadler, T; M Buteler \& DK Weaver. 2010. Novel use of nanostructured alumina as an insecticide. Pest Manag. Sci., 66:577-579.

Stadler, T; M Buteler; DK Weaver \& S Sofie. 2011. Comparative toxicity of nanostructured alumina and a commercial inert dust for Sitophilus oryzae (L.) and Rhyzopertha dominica (F.) at varying ambient humidity levels. J. Stored Prod. Res., 48:81-90.

Stefanazzi, N;T Stadler \& A Ferrero. 2011. Composition and toxic, repellent and feeding deterrent activity of essential oils against the stored-grain pests Tribolium castaneum (Coleoptera: Tenebrionidae) and Sitophilus oryzae (Coleoptera: Curculionidae). Pest Manag. Sci., 67:639-646.

Subramanyam, BH \& R Roesli. 2000. Inert dusts. pp 321379. In: Subramanyam, B. \& D.W. Hagstrum (eds.), Alternatives to pesticides in stored-product IMP, Kluwer Academic Publishers, Boston, Massachussets.

TALUKDER, FA \& PE HOWSE. 1993. Deterrent and insecticidal effects of extracts of Pithraj, Aphanamixis polystachya (Meliaceae), against Tribolium castaneum in storage. J. Chem. Ecol., 19:2463-2471.

White, GD; WL Berndt; JH SCHESSER \& CC FifIELD. 1966. Evaluation of inert dusts for the protection of stored wheat in Kansas from insect attack. ARS-USDA, 51:21 pp.

Winston, PW \& DH BATEs. 1960. Saturated solutions for the control of humidity in biological research. Ecology, 41:232-237. 